\title{
Family Ownership, Corporate Governance and Performance: Evidence from Saudi Arabia
}

\author{
Mohammed Al-Ghamdi ${ }^{1,2} \&$ Mark Rhodes $^{3}$ \\ ${ }^{1}$ Doctoral Student, Hull University Business School, UK \\ ${ }^{2}$ Lecturer, Finance and Accounting, Al Baha University, KSA \\ ${ }^{3}$ Hull University Business School, Senior Lecturer, Financial Economics. Graduate Research Director of the \\ Business School, UK \\ Correspondence: Mohammed Al-Ghamdi, 15 St David's Close, Cottingham, Post Code HU16 4NN, UK. Tel: \\ 44-77-8010-1140. E-mail: m_algam929@hotmail.com
}

Received: November 13, 2014

Accepted: December 8, 2014

Online Published: January 25, 2015

doi:10.5539/ijef.v7n2p78

URL: http://dx.doi.org/10.5539/ijef.v7n2p78

\begin{abstract}
The main objective of this study is to examine the performance of companies listed in the Saudi Stock Exchange. For this purpose, we studied and tested a sample of 792 firm-years among from 11 industrial groups for the years 2006 to 2013 and compared Family and Non-family firms. The research addresses the questions 1) Do family owned firms perform better? 2) How does concentration of ownership affect firm performance, comparing family firms to non-family ones? This research attempts to fill a research gap on the relationship or determinants of capital structure in one of the emerging markets, Saudi Arabia. This study will be implemented through a quantitative approach. Secondary data were obtained from published annual statistical data, from the company financial reports and the DataStream database.
\end{abstract}

Keywords: corporate governance, family ownership, ownership concentration, corporate performance

\section{Introduction}

In the corporate finance literature, a lot of discussion is prevalent with reference to the association that exists between corporate governance, ownership concentration and firm performance. Concentrating mainly on the United States and the Asian experience, there exists a large body of finance and law literature. It investigates the relationship between corporate governance and firm performance in many countries by means of multi-country studies or case studies of an individual country (see Claessens et al., 2000; Faccio \& Lang, 2002; Lemmon \& Lins, 2003).

A Majority of the listed firms have the status of family firm in many Arab countries; hence, it is common for the family members to possess considerable power in the management of the firm. This may be achieved through chairmanship or being a member of the board, and also by means of the control of senior management positions (OECD, 2003). It may result in conflicts of interest between the controlling family and minority stakeholders. For that, in the Arab countries, it is very important to understand the corporate governance (Saidi, 2004, 2005; Omet, 2005; Najib, 2007).

The impact of family Ownership on firm value habitually has been positive. Shleifer and Vishny (1986) found a positive relationship between ownership concentration and firm performance, arguing that this resolved agency costs by controlling and supervising activities in the firm. Holderness and Sheehan (1988) summarise that there are positive effects on firm performance with respect to a majority of the firms which have majority shareholders. Berle and Means (1932) found ownership concentration important in resolving agency issues between an organisation's owners and managers.

In this study we address the question; how does ownership concentration affect performance comparing family firms to non-family firms? To explore the association between family ownership and firm performance in listed firms, the contribution in this study, a contribution is that most other studies suffer from the problem that family ownership is not accurately measured. Avoiding significant measurement error is useful in this context a biased and inconsistent results are (largely) avoided. 
Family ownership is relatively easy to track in KSA and there are, potentially, fewer biases in the measurement and determination of family ownership than may be the case in other settings. This is because in family businesses in Saudi Arabia it is relatively easy to identify the names of members of the family. This arises because the whole family have the same family name whether they are males or females, before or after marriage. Islamic law in Saudi Arabia gives the right for a woman to keep the name of her father after marriage. Therefore, the names of second generation owners in family firms will be clear and easy to identify.

In this context, we analyse the corporate performance in the context of non-financial firms in Saudi Arabia listed on the Saudi Stock Market (SSM) for the period 2006 to 2013. The data is sourced from Datastream and the company financial reports, provinding an unbalanced panel data sample of 99 firms, corresponding to 792 firms - year observations. From the total sample, 55 firms are family-firms (about 56\% ) and 44 are non-family firms.

\section{Defining Family Owned Firms}

Authors Miller et al. (2007) have compiled a list of 28 definitions of family firms that are used in a plethora of studies in various finance and management journals globally, from 1996 to 2006. Here are some of the diverse definitions of family business. James (1991) frames the idea of family businesses either as that which is entirely or majority owned by one person or by various members of one given family. On the contrary, Jaffe (1987) has shifted the definition of family business towards the concept of any business where management or active ownership responsibility is adopted by a given set of family members. In this paper we began our study with the overarching question of how can family firms are identified. We adopt the definition of family firms based on a statistical analysis of firm characteristics. Thus, the definition of family firm in this study will be a firm where the family has ownership of a minimum of $10 \%$ of the equity of the firm, and at least one representative of the family is a member of the management board. As 16 out of 55 family firms have a CEO sourced from the family this means $29 \%$ of the CEOs in family firms are family members and $71 \%$ are outsiders or hired CEOs. Adopting this definition means 55 family firms and 44 non-family firms were selected for this study.

\section{Firm Performance Measurement}

This study will employ both the market returns and accounting measures (profitability) as possible proxies for company performance. These two measures are first, Tobins Q ratio which has the benefit of being a forward looking measure and, second, Return on Assets (ROA) which is an approximate measure of what management has achieved and is backward looking (see Demsetz and Villalonga, 2001). Most previous studies have used ROA and Tobin's Q as an indicator of firm performance, brief reference to some of these may be found in Table 1.

Table 1. Measurement of firm profitability

\begin{tabular}{llll}
\hline Name & Short & Definition & Representative studies \\
\hline Return On Assets & ROA & $\begin{array}{l}\text { A financial ratio that shows the percentage profit a company } \\
\text { earns in relation to its total Assets }\end{array}$ & $\begin{array}{l}\text { Denis \& Denis 1994, Lehmann \& } \\
\text { Weigand 2000 }\end{array}$ \\
Tobin's q ratio & Tobin's q & $\begin{array}{l}\text { The ratio of the book value of total assets minus the book value } \\
\text { of equity, plus the market value of equity to the book value of }\end{array}$ & $\begin{array}{l}\text { Demsetz Gugler \& Yurtoglu 2003, Bjuggren } \\
\text { assets. }\end{array}$ \\
& & \& Wiberg 2008, Ozkan, 2004 & Villalonga \\
\end{tabular}

\section{Related Literature and Hypotheses}

\subsection{Ownership Concentration}

There is an important relationship between family firms and firm performance, as concluded by many researchers. In East Asian firms, due to low transparency, family control could damage minority stakeholders; as stated by Faccio et al. (2001). In East Asian countries, the performance of family firms is lower than non-family firms, as observed by Claessens et al. (2002). Family firms in Norway were less productive than non-family firms, as displayed by Barth et al. (2005). Thus, researchers have found that in Western Europe firms that are run by a founding family are more profitable than nonfamily firms, further evidenced by Maury (2006). In the United States (US), family firms were found to perform better than nonfamily firms, as concluded in a study of the relationship between family firms and performance by Anderson and Reeb (2003).

In family firms, the significance of family management and family structure has been examined. In the US, France, Germany, and the UK, Bloom and Van Reenen (2007) found that there was evidence of poor 
management systems under family ownership. In the US it was found that the performance of family- CEO firms was better than nonfamily firms; but once it was run under the heir functioning as the CEO, firm value was destroyed (Villalonga \& Amit, 2006).

From the above discussion, the following hypothesis is proposed:

H1: The determinants of performance are different between family and non-family firms.

H2: There is a relationship between ownership concentration and firm performance.

\subsection{Managerial Ownership}

Theoretically there are two major hypotheses on the impact of managerial ownership on firm value. The convergence of interest hypothesis, which links the role of managerial ownership with firm performance (Jensen \& Meckling, 1976; Jensen, 1993), proposes that the share ownership of managers would help in aligning the interests of shareholders and managers. However the entrenchment hypothesis states that the firm value decreases when management holds a substantial stake in their firms as managers become more difficult to remove (Jensen \& Meckling, 1976; Stulz, 1988; Fama \& Jensen, 1983).

In this research, managerial ownership is defined as the percentage of share ownership of both executive directors and non-executive directors in line with Morck et al. (1988), McConnell and Servaes (1990) and Short and Keasey (1999). Recognizing that nonexecutive directors are not managers involved in the day-to-day management activities of the firm this research assumes that they are part of the management body in the boardroom of the one-tier system, and hence, all directors have incentives to exert control because directors are also blockholders or their representatives (Holderness, 2003).

From the above discussion, the following hypothesis is proposed:

H3: There is a relationship between Managers ownership and firm performance.

\subsection{Board Variables}

In the literature, board size is considered a significant factor in determining the efficiency of corporate governance (Pearce \& Zahra, 1992; Jensen, 1993). Some are of the opinions that since larger boards present a wider perspective and enhanced guidance on the planned operations of the firm; this makes larger boards more efficient (Pearce \& Zahra, 1992). On the contrary, according to some researchers, in the presence of a larger board size, the problems of coordination, communication and process exceed the benefits of having more people to draw on; hence, the value decreases (Yermack 1996; Eisenberg et al., 1998).

The impact on the board's effectiveness of the Chief Executive Officer's (CEO) duality is another matter discussed in the literature. Cadbury (1992) noted the possibility of opportunistic behaviour on behalf of insiders when the two positions are not separated in a report on corporate governance in UK firms. The role of chairperson (COB) and the $\mathrm{CEO}$ should be separated from each other to reduce agency problems, as debated by (Fama \& Jensen, 1983).

In line with the Companies Law (1965) in Saudi corporate governance the Company law establishes the fundamental requirements for the board structure, liabilities and responsibilities. The size of the board must be between three and eleven, it is required that one third of the board of directors has to comprise non-executives.

Three variables are incorporated in our empirical model to examine the effectiveness of the board in reducing agency problems, assumed to subsequently produce better performance. First, the total number of directors (Board size), second, a dummy variable that takes the value of 1 if the CEO and chairman of board are separate (Non-Duality), or else 0 and third, a dummy variable that takes the value of 1 if the CEO position in the firm is held by a family member (CEO family member).

From the above discussion, the following hypothesis is proposed:

H4 A: There is a relationship between profitability and board size;

$H 4$ B: There is a relationship between profitability and Non-Duality;

$H 4$ C: There is a relationship between profitability and CEO Family.

\subsection{Agency Costs and Performance}

In this paper we use two proxy measures for agency costs, which frequently appear in the accounting and financial economics literature. First proxy is asset utilisation ratio; this measure of agency costs is calculated as the ratio of annual sales to total assets. This measures the effectiveness of firm investment decisions and the ability of the management to direct assets to their most productive use. If the asset utilisation ratio is lower the 
management of the firm are seen as taking sub optimal investment decisions. Second proxy is expense ratio; calculated as operating expenses divided by annual sales. This ratio is a measure of how effectively the firm's management controls operating costs, and other direct agency costs.

\section{Assets Turnover $(A S T N)=$ Annual sales to total assets \\ Expenses ratio $($ EXPRAT) = operating expense scaled by annual sales}

H5: There is a relationship between profitability and agency costs.

\subsection{Firm Size}

Smaller firms have more room for bigger family ownership as they are likely to be closer to their inception and easier for families to support financially. Also, there may be an inverse relation of size with level of information asymmetries between external and internal investors, as stated by Rajan and Zingales (1995). Firm size was negatively related with performance; as concluded by Klein et al. (2005). As stated by Kapopoulos and Lazaretou (2007); firm size as calculated by the book value of total assets, had an inverse relation to performance. Firm size was negatively related to performance, as discovered by Farooque et al. (2007). Firm size was positively and considerably linked with Tobin's q, as concluded by $\mathrm{Hu}$ and Izumida (2008). As compared to smaller firms, larger firms display higher Tobin's q ratio, as indicated by King and Santor (2008).

From the above discussion, the following hypothesis is proposed:

H6: There is a relationship between profitability and firm size.

\subsection{Leverage}

The relationship between leverage and performance in previous research has different results, as discussed by Stiglitz (1985). A positive effect on firm performance may be expected as an outcome of monitoring performed by the lender. Conversely, the threat of bankruptcy may be increased by greater levels of debt also limiting the firm's ability to increase new debt and consequently compelling firms to lose important investment opportunities (Myers, 1977; Harris \& Raviv, 1990). Tong and Ning (2004) included that a negative signal is given by highly leveraged firms that the firm may be unable to meet financial commitments in the future. Leverage was related negatively to firm valuation, as observed by Perrini et al. (2008). There was also a negative relationship between leverage and performance measures, as proposed by $\mathrm{Hu}$ and Izumida (2008). This was explained as the agency cost of debt finance resulting from a conflict of interests between bondholders and shareholders, this because bond holders do not have the upside risk of very good performance and so shareholders prefer higher leverage.

In classical models of capital structure, firms should borrow as much as possible because of the tax shield that is offered. In this study which applies to KSA there is no effective tax shield as companies pay only zakat which is fixed, small $2.5 \%$ of net profit. Further, one of the features in Saudi's economy is the absence of income tax on citizens.

According to the above discussion, because firm size theories give different implications for the relationship between leverage and firms' performance, this research assumes either a negative or positive relationship between profitability and capital structure as is shown in the following hypothesis:

\section{H7: There is a relationship between profitability and leverage.}

\section{Model Specification}

The preceding discussion informs the model specification.

Performance $\sim f$ (ownership concentration, Managerial Ownership, Assists Turnover, Expenses Ratio, CEO Family, Board size, CEO/Chair Non-Duality, Long term debt to total assets, Total debt to total equity, Firm Size).

Table 2. Definition and measures for variables

\begin{tabular}{lll}
\hline Symbol & Descriptions and measures & Sources \\
\hline OWNCON & The percentage of total shares outstanding held by Largest & Thomson one Banker database and the \\
& Shareholders owning more than $10 \%$ of the firm shares & financial reports \\
MOWNER & The percentage of total shares held by executive directors divided & Thomson one Banker database and the \\
& by the total number of shares & financial reports \\
ARTN & Annual sales to total assets (Asset Turnover) & Datastream database and the financial \\
& & reports \\
EXPRAT & Operating expense scaled by annual sales & Datastream database and the financial \\
\hline
\end{tabular}




\begin{tabular}{|c|c|c|}
\hline & & reports \\
\hline CEO - FAMILY & $\begin{array}{l}\text { A dummy variable that takes the value of } 1 \text { if a family member } \\
\text { holds the CEO position in the firm. }\end{array}$ & Financial reports \\
\hline BRDSIZE & The total number of members on the board & Financial reports \\
\hline $\begin{array}{l}\text { CEO/Chair } \\
\text { Non-Duality }\end{array}$ & $\begin{array}{l}\text { A dummy variable that takes the value of } 1 \text { if the CEO and chair of } \\
\text { board have separate roles, otherwise } 0\end{array}$ & Financial reports \\
\hline LTDTA & $\begin{array}{l}\text { Long-Term Debt Divided by Total Assets, it is used to investigate } \\
\text { the effect of long-term debt on a firm's performance }\end{array}$ & $\begin{array}{l}\text { Datastream database and the financial } \\
\text { reports }\end{array}$ \\
\hline TDTE & Total Debt Divided by Total Equate & $\begin{array}{l}\text { Datastream database and the financial } \\
\text { reports }\end{array}$ \\
\hline F SIZE & Logarithm of total assets & $\begin{array}{l}\text { Datastream database and the financial } \\
\text { reports }\end{array}$ \\
\hline Tobin's Q & $\begin{array}{l}\text { The ratio of the book value of total assets minus the book value of } \\
\text { equity, plus the market value of equity to the book value of assets }\end{array}$ & $\begin{array}{l}\text { Datastream database and the financial } \\
\text { reports }\end{array}$ \\
\hline ROA & Ratio of the net Income divided by total Assets & $\begin{array}{l}\text { Datastream database and the financial } \\
\text { reports }\end{array}$ \\
\hline Family-Firm & $\begin{array}{l}\text { A dummy variable that takes the value of } 1 \text { if the company a family } \\
\text { firm, otherwise } 0 \text {. }\end{array}$ & \\
\hline
\end{tabular}

\section{Data Sample and the Processes of Analysis}

Data were collected mainly from secondary sources; the sample size of the study consists of all Saudi listed companies, excluding financial firms. The research sample is subjected to the following criteria:

- The main sources of secondary data collected Specifically from Datastream database, Thomson one Banker database and the financial reports of the firms.

- The research covers the period 2006 to 2013, a total of 8 consecutive years. Data for an extended period is considered necessary to draw clear statistical estimations of the relationships between variables. The rationale for using this period is summarized in the following points: 1) the reforms to Saudi Arabia's environment commenced at the beginning of 2006. 2) The implementation of the best practice of corporate governance mechanisms was embarked upon in 2006. In addition, banks and finance companies and insurance companies are excluded from our list.

\subsection{The Processes of Analysis}

In analysing the data, correlation coefficients and variance inflation factors (VIF) were used to check for multicollinearity. Multicollinearity was absent in the interaction between independent constructs.

GLS estimation of a random effects panel estimator was conducted over the eight-year sample period. By this means it will be possible to test for variations among cross-sectional units and also variations within individual units over time (Baum, 2006). This approach assumes that regression parameters are similar between various cross-sectional units and stable over time. We are also able to introduce industry fixed effects directly through the use of dummy variables.

\subsubsection{Descriptive Statistics}

Table 3 presents descriptive statistics for the variables used in our estimation. The sample contains panel data sample of 99 firms, corresponding to 792 observations. From the total sample, 55 firms are family-firms (about $56 \%$ of the firms) and 44 are non-family firms, in Saudi Arabia for the Period 2011-2013.

Table 3. Descriptive statistics for family firms variables.

\begin{tabular}{lccccc}
\hline Variable & Mean & Std. Dev. & Median & Min & Max \\
\hline Dependent Variables & & & & & \\
ROA & 0.085 & 0.093 & 0.078 & -0.6 & 0.57 \\
Tobin's Q & 1.271 & 1.104 & 0.907 & -0.44 & 9.67 \\
Independent Variables & & & & & \\
BRDSIZE & 8.29 & 1.78 & 8 & 4 & 13 \\
MANGOWN & 0.05 & 0.1 & 0 & 0 & 0.8 \\
Non/Dual & 0.96 & 0.19 & 1 & 0 & 1 \\
\hline
\end{tabular}




\begin{tabular}{lccccc}
\hline CEO-Family & 0.28 & 0.45 & 0 & 0 & 1 \\
OWNCON & 0.69 & 4.9 & 0.18 & 0 & 51.7 \\
LTDTA & 0.08 & 0.1 & 0.04 & 0 & 0.45 \\
TDTE & 0.44 & 1.93 & 0.19 & -1.93 & 36.98 \\
FSIZE & 8.75 & 1.21 & 8.99 & 0 & 10.66 \\
EXPRAT & 0.73 & 0.36 & 0.83 & -0.55 & 3.71 \\
ARTN & 0.65 & 0.55 & 0.52 & 0 & 3.05 \\
\hline
\end{tabular}

Table 4. Descriptive statistics for non-family firms

\begin{tabular}{lccccc}
\hline Variable & Mean & Std. Dev. & Median & Min & Max \\
\hline Dependent Variables & & & & & \\
ROA & 0.06 & 0.1 & 0.04 & -0.67 & 0.62 \\
Tobin's Q & 1.48 & 1.33 & 0.95 & 0.15 & 7.37 \\
Independent Variables & & & & & \\
BRDSIZE & 8 & 1.43 & 8 & 4 & 12 \\
MANGOWN & 0.01 & 0.04 & 0 & 0 & 0.38 \\
Non/Dual & 0.98 & 0.13 & 1 & 0 & 1 \\
OWNCON & 0.01 & 0.04 & 0 & 0 & 0.21 \\
LTDTA & 0.13 & 0.18 & 0.03 & 0 & 0.66 \\
TDTE & 0.53 & 0.99 & 0.09 & -0.78 & 8.34 \\
FSIZE & 8.5 & 1.16 & 8.73 & 5.85 & 11.52 \\
EXPRAT & 0.78 & 0.49 & 0.85 & -3.55 & 4.83 \\
ARTN & 0.54 & 0.63 & 0.39 & 0 & 4.81 \\
\hline
\end{tabular}

\section{Econometric Analysis (Findings for Regression Models)}

The following table shows the regressions results for the relationship between firms' performance measured by the Return on Assets (ROA) and Tobin's Q as a dependent variable and the corporate governance variables comparing family and non-family firms.

In all cases the results are jointly significant at a $1 \%$ level of significance. Note that the R-squared for the first table are in the range of $42 \%$ to $31 \%$ for family and non-family firms in the ROA. For the second table the R-squared is in the same range, $39 \%$ and $37 \%$ for family and non-family firms respectively.

Table 5. Regression results for performance measured by return on assets

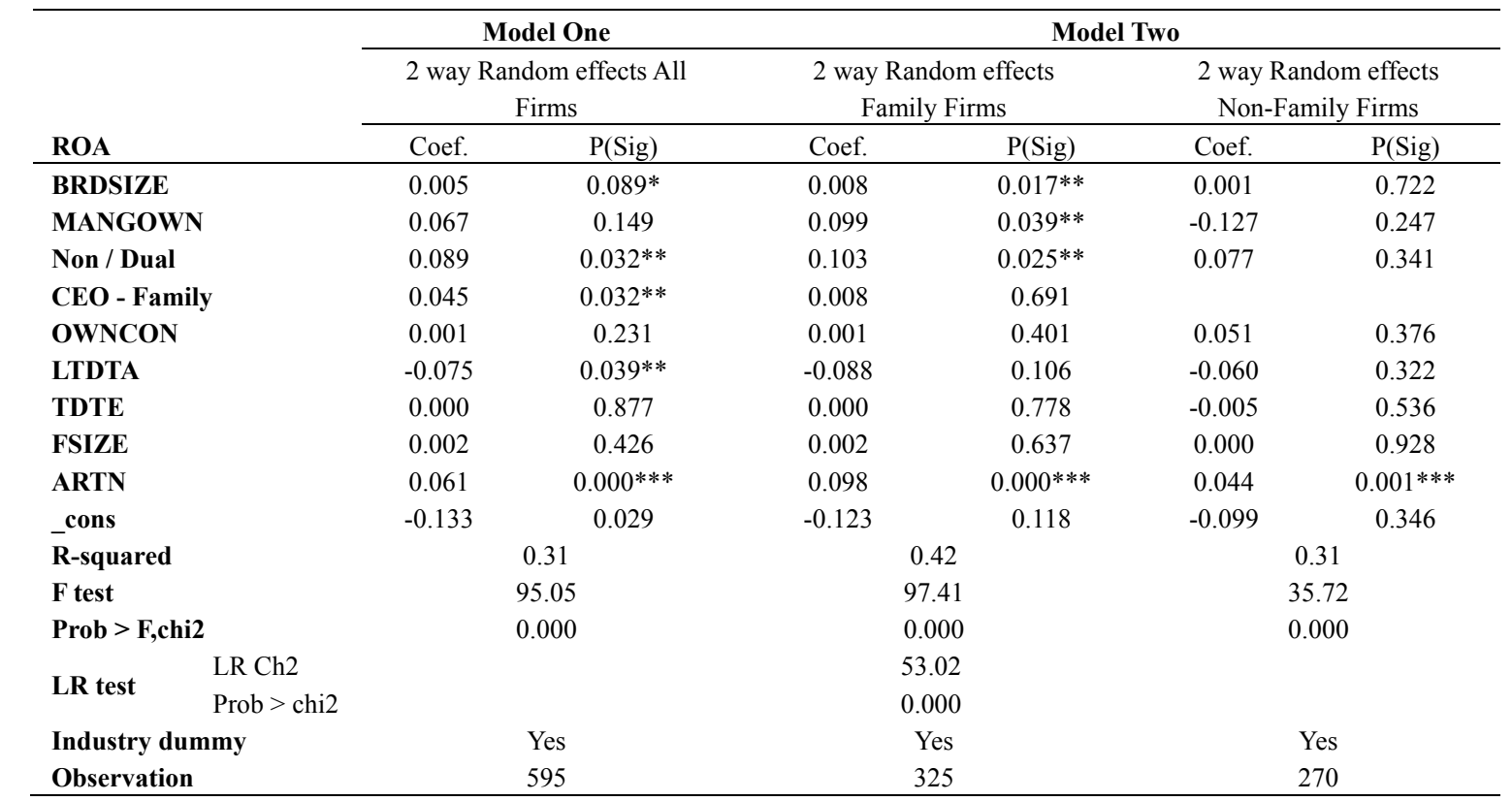

Note. *significant at $10 \%$, ** Significant at $5 \%$, *** Significant at $1 \%$. 
Tests of whether random effects are appropriate were conducted and both models were found to have significant Wald values. We therefore conclude that random effects are appropriate. A further Hausman test (not reported here) was insignificant, which confirms that fixed effects are not necessary, although our preference $a$ priori was for a random effects model. The LR test that is reported at the bottom of Tables 5 and 6 examines whether the observations on family and non-family firms might be pooled. Both for the model on return on assets and Tobin's Q we reject the null hypothesis that Model One and Model Two are equivalent and proceed to interpret the results from Model Two.

Table 6. Regression results for performance measured by Tobin's Q

\begin{tabular}{|c|c|c|c|c|c|c|}
\hline \multirow[b]{3}{*}{ Tobin's Q } & \multicolumn{2}{|c|}{ Model One } & \multicolumn{4}{|c|}{ Model Two } \\
\hline & \multicolumn{2}{|c|}{2 way Random effects All Firms } & \multicolumn{2}{|c|}{$\begin{array}{c}2 \text { way Random effects } \\
\text { Family Firms }\end{array}$} & \multicolumn{2}{|c|}{$\begin{array}{c}2 \text { way Random effects } \\
\text { Non-Family Firms }\end{array}$} \\
\hline & Coef. & $\mathrm{P}($ Sig $)$ & Coef. & $\mathrm{P}($ Sig) & Coef. & $\mathrm{P}($ Sig) \\
\hline BRDSIZE & 0.018 & 0.671 & -0.018 & 0.686 & 0.081 & 0.267 \\
\hline MANGOWN & 0.512 & 0.413 & 0.959 & 0.112 & 0.426 & 0.763 \\
\hline Non / Dual & 0.100 & 0.886 & 1.494 & $0.025 * *$ & -1.598 & 0.249 \\
\hline CEO - Family & 0.320 & 0.353 & 0.414 & 0.189 & & \\
\hline OWNCON & 0.028 & 0.254 & 0.036 & $0.057^{*}$ & 1.341 & 0.152 \\
\hline LTDTA & -1.637 & $0.001 * * *$ & 0.563 & 0.429 & -2.798 & $0.001 * * *$ \\
\hline TDTE & -0.033 & 0.155 & -0.026 & 0.185 & -0.121 & 0.312 \\
\hline FSIZE & 0.055 & 0.305 & 0.194 & $0.005 * * *$ & -0.044 & 0.587 \\
\hline ARTN & 0.309 & $0.023 * *$ & 1.157 & $0.000 * * *$ & 0.152 & 0.411 \\
\hline _cons & 0.898 & 0.362 & -2.551 & 0.000 & 3.118 & 0.069 \\
\hline R-squared & \multicolumn{2}{|c|}{0.22} & \multicolumn{2}{|c|}{0.39} & \multicolumn{2}{|c|}{0.37} \\
\hline F test & \multicolumn{2}{|c|}{51.23} & \multicolumn{2}{|c|}{78.99} & \multicolumn{2}{|c|}{40.44} \\
\hline Prob > F,chi2 & \multicolumn{2}{|c|}{0.000} & \multicolumn{2}{|c|}{0.000} & \multicolumn{2}{|c|}{0.000} \\
\hline LR test $\quad$ LR Ch2 & \multicolumn{6}{|c|}{91.26} \\
\hline Prob $>$ chi 2 & \multicolumn{6}{|c|}{0.000} \\
\hline Industry dummy & \multicolumn{2}{|c|}{ Yes } & \multicolumn{2}{|c|}{ Yes } & \multicolumn{2}{|c|}{ Yes } \\
\hline Observation & & & & & & \\
\hline
\end{tabular}

Note. * significant at $10 \%, * *$ Significant at $5 \%, * * *$ Significant at $1 \%$.

\subsection{Ownership Concentration}

In the results from (Table 5), the coefficient on the variable ownership concentration is always positive but has an insignificant effect on performance measured by ROA. The result is consistent with the evidence of (Demsetz \& Lehn, 1985) and (Demsetz \& Villalonga, 2001) that ownership concentration has no systematic relationship with firm value. Based on this finding, Hypothesis ( 2 which stated there is relationship between ownership concentration and firm performance is not supported.

Additionally, the finding for ownership concentration and Tobin's Q in non-family firms is consistent with our expectations, as we find the coefficient is positive though statistically insignificant. Conversely, there is a significant positive relationship between ownership concentration and Tobin's Q in the family firms which means that as ownership concentration increases in family firms the performance of Saudi firms' increases as shown in the (Table 6). The finding in this study is also consistent with that of (Haniffa \& Hudaib, 2006) in their study on the positive relationship between the ownership of the top five shareholders and firm performance in Malaysia, also, (Kapopoulos \& Lazaretou, 2007) who suggested that when a firm has high concentrated ownership, the profitability of that firm is also high. In conclusion, Hypothesis two is partially supported in this study and for that is fail to reject.

One of the reasons for this positive relationship could be that increasing ownership concentration affects positively Tobin's Q as large shareholders in family firms would play an important role to increase their own wealth though a rise in the price of shares (Shleifer \& Vishny, 1986).

\subsection{Managerial Ownership}

Managerial ownership we found a significant positive relationship between managerial ownership and ROA in family firms. This, together with the results of CEO non-duality indicates that there is a better association of the 
goals of shareholders and managers where managers own stock. In contrast, although there is a positive relationship in family firms between ownership concentration and performance this is statistically insignificant.

Moreover, evidence is also provided by the significant positive relationship between managerial ownership and performance measured by Tobin's Q in family firms. This supports the view that investors, especially for family firms' view managers as good stewards of the firm's resources where they have a direct interest in the firms performance. So, regarding family firms the result shows a significant relationship between managerial ownership and firm performance as measured by ROA or Tobin's Q based on this finding, Hypothesis three for family firms, which stated that there is a relationship between managerial ownership and firm performance is supported.

Regarding non-family firms, the results show an insignificant relationship between managerial ownership and firm performance as measured by ROA or Tobin's Q and we note that the coefficient on the variable managerial ownership with ROA is negative. A significant negative finding would have been consistent with some earlier studies such as (Morck et al., 1988; Harris \& Raviv, 1988; Stulz, 1988) with the implication that the more shares the managers hold, the more is their entrenchment and their ability expropriate the firm's resources for their own benefits. However based on our findings, Hypothesis (3) for non-family firms, which stated that there is a relationship between managerial ownership and firm performance ROA or Tobin's Q, is not supported.

In sum, this study suggests that the firms with managerial ownership, particularly in respect of family firms, have higher performance. This is shown in the relationship between managerial ownership and performance in Tables 5 and 6.This result suggests that, as management ownership rises, agency problems between management and outside shareholders are more likely to be resolved leading to higher performance.

\subsection{Agency Costs}

Agency costs in family and non-family firms indeed have a negative and significant impact on ROA in KSA. This is seen in the positive and statistically significant coefficient on ARTN. In this case, there is a relationship between agency costs and firm performance, supporting Hypothesis (5). The coefficient of 0.098 of family firms in Table 5 can be interpreted as: a rise of 1 unit of the ratio of turnover to assets (decline in agency costs) results in a $9.8 \%$ increase in the ROA. A similar relationship is found in family firms when firm performance is measured by Tobin's Q.

In terms of ownership structure in family firms', the result also indicates that a high level of managerial ownership contributes to reducing agency costs. As shown in Table (5) managerial ownership has a positive influence on firm performance at a 5\% level. This is not surprising since managers ownership plays a significant role in decision-making and a firm's performance, resulting in a mitigation of agency costs. This finding is consistent with (Gul et al., 2012; Mustapha \& Ahmed, 2011).

\subsection{Board Structure}

In this sub-section, we examine the relationship between board structure (board size, non/duality and CEO-family) and corporate performance. The results are shown in Tables 5 and 6 . In family firms, the board size has a positive significant regression coefficient a result which supports the fourth hypothesis that there is a relationship between board structure (board size) and firm performance. This positive relationship indicates that when the board size increases, the performance of the family firms will increase. This is similar to previous studies such as (Pearce \& Zahra, 1992). Conversely, however, when performance is measured by Tobin's Q the result shows an insignificant relationship between board size and firm performance.

Further there is a positive and significant relationship between non duality and ROA in the family firms. Also, there is a positive and significant relationship between non duality and Tobin's Q in family firms. These results are consistent with the view that the board's monitoring is unlikely to be as effective if the same person holds the two top positions. The results further suggest that the CEO can additionally exert a positive effect on firm performance by holding board membership. Firms with CEO board members are likely to have better or more efficient governance mechanisms, which should contribute to enhanced performance. This result suggests that if the CEO is a board member, he or she may facilitate and participate in the decision making process rather than dominate the decisions of the board, as may be the case when he/she is CEO and chairman together. This result supports the fourth hypothesis which stated that there is a relationship between board structure (nonduality) and firm performance.

In Saudi Arabia as in many other Arab and developing countries, management and the board of directors in family firms are frequently controlled by members of the families. Therefore, the board structures in family firms are expected to have an impact on corporate performance. Regarding non-family firms, the results show an 
insignificant relationship between non-duality and firm performance (as measured by the ROA or Tobin's Q). Based on this finding, the Hypothesis (4B) for non-family firms, which stated that there is a relationship between non duality and firm performance ROA or Tobin's Q, is not supported. As far as we know, only (Elsayed, 2007) has carried out research in an Arab nation on this question (in Egypt) and found CEO duality had no influence on corporate performance.

\subsection{Firm Size}

There is evidence of a significant positive relationship between firm size and Tobin's Q in family firms (Table 6), although this is the only occurrence of a significant effect. Theoretical explanations for this effect are often presented as market power and economies of scale. Further work might be undertaken to examine whether this finding for family firms may have arisen because profitable firms that have grown without the need for external financing (and hence the dilution of family shareholding) are in essence self selected for the sample.

However the result is not consistent with previous research. (Sarkar \& Sarkar, 2000) conclude that larger firms can be less efficient than smaller ones because of the loss of control by top managers over strategic and operational activities within the firm. Lang and Stulz (1994) find a decrease in firm returns as the firm becomes larger and more diversified. Based on this finding, the Hypothesis (6) for family firms, which stated that there is a relationship between firm size and firm performance, is supported.

\subsection{Leverage}

Leverage has a negative, though insignificant regression coefficient for performance (measured by ROA) in family firms, with an estimated coefficient of -0.088 . For non-family firms there is a significant negative relationship between leverage and firm performance (as measured by the Tobin's Q) with an estimated coefficient of -2.798 statistically significant at a $99 \%$ level. Since we expect that too much debt increases the risk of bankruptcy and limits the firm's ability to raise new capital these results are consistent with expectations and consistent with other findings (Myers, 1977; Harris \& Raviv, 1990). It would appear that in the case of both family and non-family firms the need to raise capital through debt may be a signal that the firms prospects are relatively poor. Given the absent or low levels of taxation in KSA there are no anticipated direct benefits in the form of tax shields offered by debt and so a negative finding is more likely in this context. This finding is consistent with studies such as Tong and Ning (2004) who found that highly leveraged firms provide a negative signal that the firm faces future financial problems.

This negative relationship for leverage in explaining the performance of family firms in Saudi Arabia companies during this period 2006-2013 may be consistent with the agency based theory that a highly leveraged firm in financial crisis makes inefficient investment decisions and this leads to a decline in value. Another explanation is that the stock market pays particular attention to the firm's ability to repay loans, especially short-term loans. This may lead to poor performance in firms with very high leverage. Therefore, Hypothesis (7), which indicates that there is a relationship between leverage and firm performance, is not supported. These results are consistent with the research findings of (Onaolapo \& Kajola, 2010; Fosberg \& Ghosh, 2006).

\section{Conclusion}

The determinants of corporate performance for Saudi companies are studied in this paper. This is in a context where, most listed firms are family firms and, the boards and management are frequently dominated by the families.

Our analysis revealed that ownership concentration has no systematic relationship with firm performance if measured by ROA. Conversely, ownership concentration in family firms has a significant positive relationship with Tobin's Q. There is a strong relationship between performance and managerial ownership in family firms whether performance is measured as ROA or Tobin's Q. This is in contrast to the findings for non-family firms. In addition, we find some evidence for a link between performance and board size in family firms. The findings support the view that $\mathrm{CEO}$ non duality is important for performance in family firms.

There is therefore evidence that agency costs are important for Saudi companies and that these influences are different in their effects on family as opposed to non-family firms. This is reinforced by the findings on agency costs when measured directly in the form of turnover ratios. However it appears that the potential constraining effects of debt on the behaviour of a firm's managers are not influential, or at least insufficient in overcoming the greater received risks from firms that are highly levered. This may inform the interpretation of result in a setting where debt presents a tax shield for companies, which is not the case for Saudi Arabia. 


\section{References}

Anderson, R. C., \& Reeb, D. M. (2003). Founding-family ownership, corporate diversification, and firm leverage. Journal of Law \& Economics, 46, 653-680. http://www.jstor.org/stable/10.1086/377115

Barth, E., Gulbrandsen, T., \& Schøne, P. (2005). Family ownership and productivity: the role of owner-management. Journal of Corporate Finance, 11(1-2), 107-127. http://dx.doi.org/10.1016/j.jcorpfin

Baum, C. F. (2006). Time-series filtering techniques in Stata. Presented at NASUG5.

Berle, A. A. Jr., \& Means, G. C. (1932). The Modern Corporation and Private Property. New York, NY: Macmillan. http://dx.doi.org/10.1177/0894486509360520

Bjuggren, P. O., \& Wiberg, D. (2008). Industry specific effects in investment performance and valuation of firms. Empirica, 35(3), 279-291. http://dx.doi.org/10.1007/s10663-008-9064-5

Bloomn, V., \& Reenen, J. (2007). Measuring and Explaining Management Practices across Firms and Countries. Quarterly Journal of Economics, 122(4), 1351-1408. http://dx.doi.org/10.1162/qjec.2007.122.4.1351

Cadbury. (1992). Report of the Committee on the Financial Aspects of Corporate Governance. Gee Publications, December. Retrieved from http://www.ecgn.org/ecgn/docs/codes/cadbury.pdf

Claessens, S., Simeon, D., Joseph, P. H., F., \& Larry, H. P. L. (2002). Disentangling the incentive and entrenchment effects of large shareholdings. Journal of Finance, 57, 2741-2772. http://dx.doi.org/10.1111/1540-6261.00511

Demsetz, H., \& Lehn, K. (1985). The structure of corporate ownership: Causes and consequences. Journal of Political Economy, 93(6), 1155. http://dx.doi.org/10.1086/261354

Demsetz, H., \& Villalonga, B. (2001). Ownership structure and corporate performance. Journal of Corporate Finance, 7, 209-233. http://dx.doi.org/10.1016/S0929-1199(01)00020-7

Denis, D. J., \& Denis, D. K. (1994). Majority owner-managers and organizational efficiency. Journal of Corporate Finance, 1(1), 91. http://dx.doi.org/10.1016/0929-1199(94)90011-6

Eisenberg, T., Sundgren, S., \& Wells, M. (1998). Larger Board Size and Decreasing Firm Value in Small Firms. Journal of Financial Economics, 48, 35-54. http://dx.doi.org/10.1016/S0304-405X(98)00003-8

Elsayed, K. (2007). Does CEO Duality Really Affect Corporate Governance? Corporate Governance: An International Review, 15, 1203-1214. http://dx.doi.org/10.1111/j.1467-8683.2007.00641.x

Faccio, M., \& Larry, H. P. L. (2002). The Ultimate Ownership in Western European Corporations. Journal of Financial Economics, 65(3), 365-395. http://dx.doi.org/10.1016/S0304-405X(02)00146-0

Faccio, M., Lang, L. H. P., \& Young, L. (2001). Dividends and Expropriation. American Economic Review, 91(1), 54-78. http://dx.doi.org/10.1257/aer.91.1.54

Fama, E., \& Jensen, M. C. (1983). Separation of ownership and control. Journal of Law \& Economics, 26, 301325. http://dx.doi.org/10.1086/467037

Farooque, O. A., Zijl, T. V., Dunstan, K., \& Karim, A. K. M. W. (2007). Corporate governance in Bangladesh: Link between ownership and financial performance. Corporate Governance: An International Review, 15(6), 1453-1468. http://dx.doi.org/10.1111/j.1467-8683.2007.00657.x

Gugler, K., \& Yurtoglu, B. B. (2003). Corporate Governance and Dividend Pay-out Policy in Germany. European Economic Review, 4, 731-758. http://dx.doi.org/10.1016/S0014-2921(02)00291-X

Gul, S., Sajid, M., Razzaq, N., \& Afzal, F. (2012). Agency Cost, Corporate Governance and Ownership Structure. International Journal of Business and Social Sciences, 3(9).

Harris, M., \& Artur, R. (1990). Capital structure and the information role of debt. Journal of Finance, 45, 321349. http://dx.doi.org/10.1111/j.1540-6261.1990.tb03693.x

Harris, M., \& Raviv, A. (1988). Corporate control contests and capital structure. Journal of Financial Economics, 20, 55-86. http://dx.doi.org/10.1016/0304-405X(88)90040-2

Holderness, C. (2003). A Survey of Blockholders and Corporate Control. Economic Policy Review, 9, 51-63.

Holderness, C. G., \& Dennis, P. S. (1988). The role of majority shareholders in publicly held corporations. Journal of Financial Economics, 20, 317-346. http://dx.doi.org/10.1016/0304-405X(88)90049-9

Hu, Y., \& Izumida, S. (2008). Ownership concentration and corporate performance: A causal analysis with 
Japanese panel data. Journal of Corporate governance, 16(4), 342-358. http://dx.doi.org/10.1111/j.1467-8683.2008.00690.x

Ibrahim, H., \& Abdul, S. F. (2011). Corporate governance mechanisms and performance of public listed family ownership $\mathrm{n}$ Malaysia. International Journal of Economics and Finance, 3(1), 105-115. http://dx.doi.org/10.5539/ijef.v3n1p105

James, Jr. H. S. (1999). Owner as Manager, Extended Horizons and the Family Firm. International Journal of Economics of Business, 6(1), 41-55. http://dx.doi.org/10.1080/13571519984304

Jensen, M. C. (1993). The modern industrial revolution, exit, and the failure of internal control systems. Journal of Finance, 48, 831-880. http://dx.doi.org/10.1111/j.1540-6261.1993.tb04022.x

Jensen, M., \& William, M. (1976). Theory of the Firm: Managerial Behaviour, Agency Costs, and Capital Structure. Journal. Financ. Econ., 3, 305-360. http://dx.doi.org/10.1016/0304-405X

Kapopoulos, P., \& Lazaretou, S. (2007). Corporate Ownership structure and firm performance: evidence from Greek firms. Journal of Corporate Governance, 15(2), $144-158$. http://dx.doi.org/10.1111/j.1467-8683.2007.00551.x

King, M. R., \& Santor, E. (2008). Family values: ownership structure, performance and capital structure of Canadian firms. Journal of Banking and Finance, 32, 2423-2432. http://dx.doi.org/10.1016/j.jbankfin.2008.02.002

Lehmann, E., \& Weigand, J. (2000). Does the Governed Corporation Perform Better? Governance structures and corporate performance in Germany. Review of Finance, 4(2), 157. http://dx.doi.org/10.1023/A:1009896709767

Lemmon, M. L., \& Lins, K. V. (2003). Ownership structure, corporate governance, and firm value: Evidence from the East Asian financial crisis. Journal of Finance, 58, 1445-1468. http://dx.doi.org/10.1111/1540-6261.00573

Maury, B. (2006). Family ownership and firm performance: Empirical evidence from Western European corporations. Journal of Corporate Finance, 12(2), 321-341. http://dx.doi.org/10.1016/j.jcorpfin.2005

McConaughy, D., \& Matthews, C. (2001). Founding family controlled firms: performance, risk and value. Journal of Small Business Management, 39, 31-49. http://dx.doi.org/10.1111/0447-2778.00004

McConnell, J. J., \& Servaes, H. (1990). Additional evidence on equity ownership and corporate value. Journal of Financial Economics, 27, 595-612. http://dx.doi.org/10.1016/0304-405X(90)90069-C

Miller, D., Le Breton-Miller, I., Lester, R. H., \& Cannella, A. (2007). Are family firms' really superior performers? Journal of Corporate Finance, 13, 829-858. http://dx.doi.org/10.1016/j.jcorpfin.2007.03.004

Morck, R., Shleifer, A., \& Vishny, R. (1988). Management Ownership and Market Valuation: An Empirical Analysis. Journal of Financial $293-315$. http://dx.doi.org/10.1016/0304-405X(88)90048-7

Mustapha, M., \& Ahmad, A. C. (2011). Agency theory and managerial ownership: evidence from Malaysia. Managerial Auditing Journal, 26(5), 419-436. http://dx.doi.org/10.1108/02686901111129571

Najib, H. (2007). State of Corporate Governance in Arab Countries: An Overview. Munich Personal RePEc Archive. Retrieved from http://mpra.ub.uni-muenchen.de/4566/

Omet, G. (2005). Ownership Structures in MENA Countries: Listed Companies state-Owned, Family Enterprises and Some Policy Implications. MENA Regional Corporate Governance Forum: Advancing the Corporate Governance Agenda in MENA. 14-15 September, 2005. Retrieved from http://www.oecd.org/dataoecd/26/2/35402110.pdf

Pearce, J. A., \& Zahra, S. A. (1992). Board Composition from a Strategic Contingency Perspective. Journal of Management Studies, 29, 411-438. http://dx.doi.org/10.1111/j.1467-6486.1992.tb00672.x

Perrini, F., \& Minoja, M. (2008). Strategizing corporate social responsibility: evidence from an italian medium-sized, family owned company. Business Ethics: A European Review, 17(1), 47-63. http://dx.doi.org/10.1111/j.1467-8683.2008.00695.x

Rajan, R., \& Zingales, L. (1995). What Do Know About Capital Structure? Some Evidence from International Data. The Journal of Finance, 50, 1421-1460. http://dx.doi.org/10.1111/j.1540-6261.1995.tb05184.x

Saidi, N. (2004). Corporate Governance in MENA Countries: Improving Transparency \& Disclosure. The 
Second Middle East and North Africa Regional Corporate Governance Reform. Retrieved from http://www.oecd.org/dataoecd/17/42/33944145.pdf

Saidi, N. (2005). Corporate Governance in the Arab Countries: Role of the Banking System in Ensuring Transparency \& Disclosure, Forum on Corporate Governance in Banks and Financial Institution in Line with International Standards \& Practices. Retrieved from http://www.gcgf.org/ifcext/cgf.nsf/Content/Home

Sarkar, J., \& Subrata, S. (2000). Large Shareholder Activism in Corporate Governance in Developing Countries: Evidence from India. International Review of Finance, 1(3), 161-194. http://dx.doi.org/10.1111/1468-2443.00010

Shleifer, A., \& Vishny, R. W. (1986). Large shareholders and corporate control. Journal of Political Economy, 94(3), 461-488. http://dx.doi.org/10.1086/261385

Short, H., \& Keasey, K. (1999). Managerial Ownership and the Performance of Firms: Evidence from the UK. Journal of Corporate Finance, 5, 79-101. http://dx.doi.org/10.1016/S0929-1199(98)00016-9

Singh, M., \& Davidson III, W. N. (2003). Agency costs, ownership structure and corporate governance mechanisms. Journal of Banking \& $\quad$ Finance, $27, \quad 793-816$. http://dx.doi.org/10.1016/S0378-4266(01)00260-6

Stulz, R. M. (1988). Managerial control of voting rights: Financing policies and the market for corporate control. Journal of Financial Economics, 20, 25-34. http://dx.doi.org/10.1016/0304-405X(88)90039-6

Tong, S., \& Ning, Y. (2004). Does Capital Structure Affect Institutional Investor Choices? The Journal of Investing, 13, 53-66. http://dx.doi.org/10.3905/joi.2004.450757

Villalonga, B., \& Amit, R. (2006). How do family ownership, control and management affect firm value. Journal of Financial Economics, 80(2), 385-417. http://dx.doi.org/10.1016/j.jfineco.2004.12.005

Yermack, D. (1996). Higher market valuation of companies with a small board of directors. Journal of Financial Economics, 40, 185-221. http://dx.doi.org/10.1016/0304-405X(95)00844-5

\section{Copyrights}

Copyright for this article is retained by the author(s), with first publication rights granted to the journal.

This is an open-access article distributed under the terms and conditions of the Creative Commons Attribution license (http://creativecommons.org/licenses/by/3.0/). 